\title{
Factors influencing the distribution of nereid polychaetes: the sulfide aspect
}

\author{
Gilles Miron*, Erik Kristensen \\ Institute of Biology, Odense University, DK-5230 Odense M, Denmark
}

\begin{abstract}
A study of the spatial distribution of 3 species of nereid polychaetes (Nereis virens, $N$. diversicolor and $N$. succinea) was conducted during fall 1991 in Danish estuarine waters. Results from field data (Kerteminde Fjord/Kertinge Nor and Norsminde Fjord) suggested that pore water sulfide ( $\mathrm{HS}^{-}$) acts on the distribution of these species. $N$. virens was confined to low-sulfidic areas $(<50 \mu M)$ while $N$. succinea was found in high-sulfidic sediments (from 50 to $2000 \mu \mathrm{M}$ ). $N$. diversicolor, on the other hand, showed a broader distribution with respect to pore water sulfide. Complementary tank experiments indicated that all 3 species preferred non-sulfidic sediments in allopatry, whereas $N$. diversicolor was excluded from the non-sulfidic compartment of tanks in sympatry with each of the other 2 species. Mortality rates indicated that $N$. virens was the least sulfide-tolerant species whereas the other species showed some sort of adaptation with respect to pore water sulfide. Tank experiments and coexistence coefficients from field data indicated that interspecific competition is an important determinant of nereid distribution patterns, particularly for populations of $N$. diversicolor. Field data and results from laboratory tank experiments suggest that $N$. succinea is closely associated with mussel beds.
\end{abstract}

\section{INTRODUCTION}

Studies of marine soft-bottom communities have generally revealed that environmental factors are to a great extent responsible for the large-scale distribution of benthic infauna (Fitzhugh 1984, Hylleberg \& Nateewathana 1984, Miron \& Desrosiers 1990) while biological interactions, in a variety of forms, usually explain most of the small-scale spatial arrangements (Woodin 1974, Davey \& George 1986, Kristensen 1988, Miron et al. 1991a). Too little attention has been given to abiotic influences and physiological tolerances on patterns of habitat segregation, especially among closely related species (Dunson \& Travis 1991). In this respect, the notion of physiological niche (Spotila et al. 1989) becomes important in explaining the spatial arrangement of species.

Nereid polychaetes commonly live in the intertidal zone of estuarine and brackish waters, normally in sediments of medium to high organic content (Muus 1967). Organically enriched environments are prone to

\footnotetext{
- Present address: GIROQ, Département de Biologie, Université Laval, Ste-Foy, Québec, Canada G1K 7P4
}

develop hypoxia and anoxia because of their high $\mathrm{O}_{2}$ demand (Llanso 1991). The activity of heterotrophic organisms maintains reducing conditions below a thin oxidized surface layer in most coastal sediments (Revsbech \& Jørgensen 1986). This stratification provides the basis for bacterial sulfate reduction in the deeper anoxic sediment where sulfate is reduced to toxic sulfide (Jørgensen 1977, Revsbech \& Jørgensen 1986, Sampou \& Oviatt 1991). Sulfide, the toxicity of which results from inhibition of the electron transport chain in aerobic respiration (Torrans \& Clemens 1982), may be important for the distribution (Fenchel 1969) and density variations (Powell et al. 1983) of benthic organisms.

Many studies have examined the tolerance (or resistance) of soft-bottom infauna in relation to sulfide or low $\mathrm{O}_{2}$ availability (Theede et al. 1969, Swanson \& Sinderman 1979, Jørgensen 1980, Degn \& Kristensen 1981, Stachowitsch 1984, Jensen 1986, Llanso 1991). However, there is little work on the direct role of sulfide in the distribution patterns or population dynamics of benthic animals. Recently, Vismann (1990) showed that different capacities of $\mathrm{HS}^{-}$detoxification could explain the distribution of the nereids Nereis virens and $N$. diversicolor in the same area 
The purpose of this study was to investigate the distribution of 3 common species of nereid polychaetes (Nereis virens, $N$. diversicolor and $N$. succinea) in relation to pore water sulfide concentration. The effect of sulfide on the distribution pattern of nereid polychaetes is evaluated in terms of interspecific interactions among the 3 species.

\section{MATERIALS AND METHODS}

Field study. Study site: The study was carried out in the Kerteminde Fjord/Kertinge Nor system $\left(8.61 \mathrm{~km}^{2}\right)$, a shallow mesohaline estuary situated $10 \mathrm{~km}$ east of Odense, on the island of Funen (Fyn), Denmark (Fig. 1). The system is about $7 \mathrm{~km}$ long and its width varies from 0.3 to $3 \mathrm{~km}$. The mean water depth is $4 \mathrm{~m}$ in the fjord and $2.5 \mathrm{~m}$ in the nor. A maximum depth of $8 \mathrm{~m}$ is found in a trough in the middle of the fjord. Water temperature varies between $-1{ }^{\circ} \mathrm{C}$ in winter to $20^{\circ} \mathrm{C}$ in summer (Funen County Council 1991). A small salinity gradient is observed from the southwestern part of the nor $(17.7 \%$ ) to the mouth of the fjord in the east $(20.0 \%)$. The gradient is, however, dependent on winds and rainfalls and should play a minor role with respect to the distribution of the nereid species. The water mass of the system, which is affected only by limited freshwater runoff and/or discharges, is exchanged by tides with saline (21 to $24 \%$ ) water from the Store Bæalt entering the fjord through a narrow inlet $(60 \mathrm{~m})$. Residence time of water is around $1.5 \mathrm{yr}$ in the nor and 2 to $3 \mathrm{~d}$ in the fjord (Fyns Amt 1992). Maximum tidal amplitude is $0.3 \mathrm{~m}$ but varies significantly depending on wind direction. Four zones characterized by distinct sediment types dominate the area. A homogeneous zone largely composed of sand is found throughout the fjord and nor system between depths of 0 and $2 \mathrm{~m}$. More heterogeneous sediment is found in a narrow zone in the middle of the fjord at the same depths, while a soft silty sediment zone with a dense mussel bed (Mytilus edulis) occurs around a small island near the mouth of the fjord. At depths greater than $2 \mathrm{~m}$ in the nor, the sediment is characterized by black anoxic mud covered by a macrophyte mat (Fjordbiologisk Laboratorium 1992). Vegetation in the fjord is scanty and dominated by brown algae

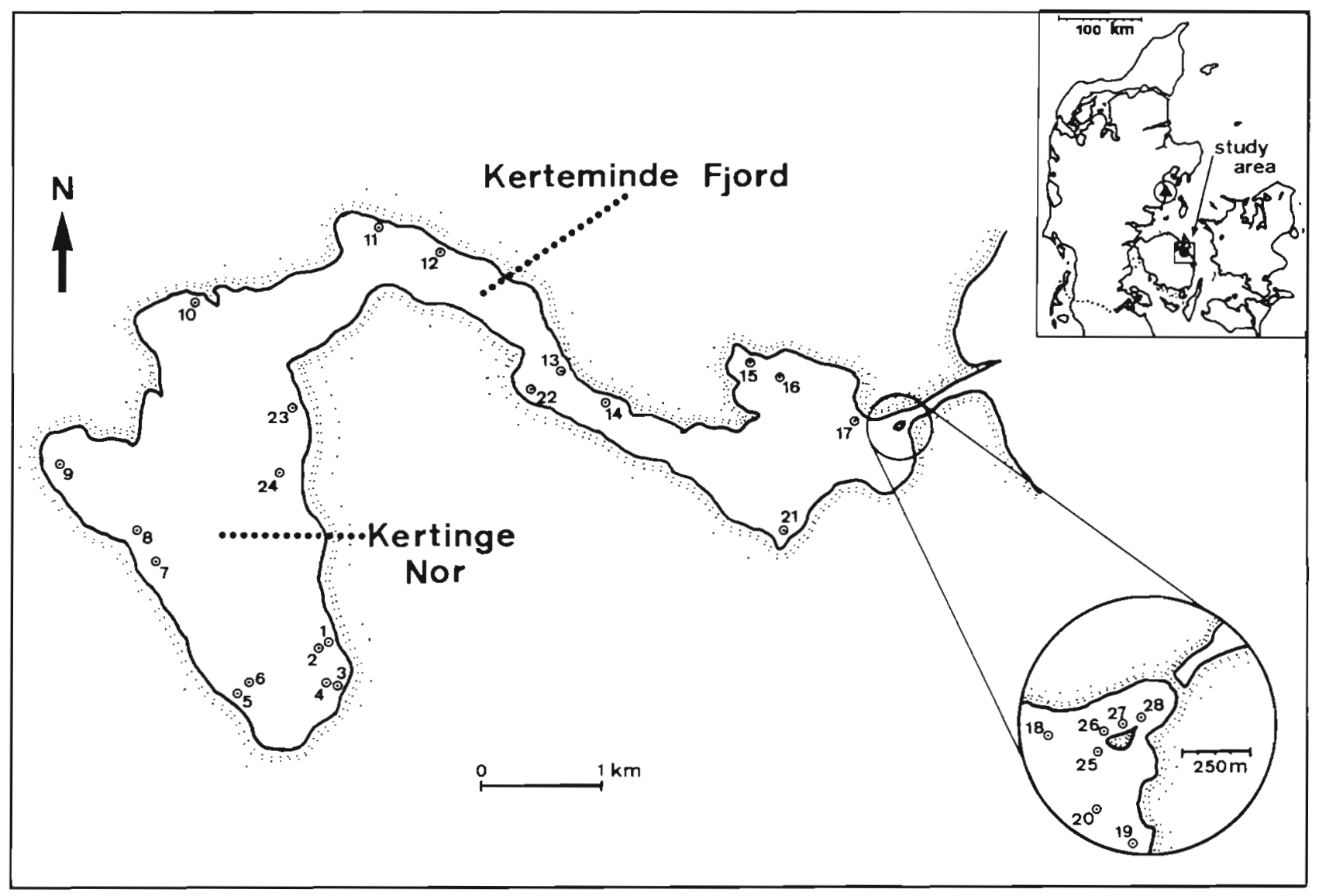

Fig. 1. The Kerteminde Fjord/Kertinge Nor system, Denmark: distribution of sampling stations. Circled triangle in inset shows location of Norsminde Fjord 
(Fucus vesiculosus). In the nor, a belt of vegetationfree sediment is found between depths of 0 and $2 \mathrm{~m}$. At depths greater than $2 \mathrm{~m}$, vegetation is much more important and is dominated by Chaetomorpha linum and Cladophora sericea (Fyns Amt 1992). Eelgrass Zostera marina, pondweeds Ruppia maritima and $R$. cirrhosa and other macrophytes (Potamogeton pectinaris and Zannichellia palestris) are also important (Fyns Amt 1992). The uppermost edge of the western part of the nor is covered with a small salt marsh dominated by Phragmites spp. The entire system is dominated by the ascidian Ciona intestinalis and the jellyfish Aurelia aurita, which control, almost exclusively, the biomass of phyto- and zooplankton (Riisgård pers. comm.). Polychaetes (mainly nereids) and bivalves (Macoma balthica and Mya arenaria) are limited to sediments above $2 \mathrm{~m}$ depth.

Norsminde Fjord is a similar shallow mesohaline estuary. It is found on the east coast of Jutland (Jylland), $20 \mathrm{~km}$ south of Århus (see Fig. 1). A description of Norsminde Fjord is given by Kristensen (1988). The sampling done in the present study showed that the mussel bed had spread toward the north in the entrance of the fjord compared to what was observed in 1978 by Kristensen (1988).

Sampling procedures: Sediments and nereids were collected from Kerteminde Fjord/Kertinge Nor during September and October 1991 from 28 stations distributed between the shoreline and the isobath of $1 \mathrm{~m}$. At each station, 3 to 5 (depending on nereid density) sediment cores of $1 / 60 \mathrm{~m}^{2}$ were taken by a $30 \mathrm{~cm}$ long $\times 15 \mathrm{~cm}$ i.d. cylindrical steel corer. Cores were presieved in the field through a $1 \mathrm{~mm}$ mesh sieve and all nereids collected. Water temperature and salinity were measured at each station. Worms were fixed in the laboratory with $4 \%$ buffered formalin within $3 \mathrm{~h}$ and later counted for density and weighed. Weight was determined using the partial weight method established by Desrosiers et al. (1988) for the first 25 segments.

Data from a transect comprising Stns 28, 27, 26, 25 , $18,17,16$ and 15 in Kerteminde Fjord were compared to results from a similar transect in Norsminde Fjord, where the nereid community has been well studied (Kristensen 1984, 1988). Six of Kristensen's (1988) original stations were sampled (Stns 1, 2, 3, 5, 6 and 8) on 20 October 1991 to examine long-term changes in nereid distribution. The nereid density and distribution at this location were determined as described above.

Coexistence between pairs of species was described for the 2 study areas using a modified version (Kristensen 1988) of the symmetric overlap index formulated by Schoener (1974). According to Kristensen (1988), this index does not necessarily imply competition but should provide some indication of the strength of interspecific interactions.
Sediment characteristics: For each station (Kerteminde Fjord/Kertinge Nor system and Norsminde Fjord), 3 sediment cores were collected with $5.0 \mathrm{~cm}$ i.d. acrylic core liners. Pore water sulfide concentrations were determined in the laboratory immediately (within $3 \mathrm{~h}$ ) following sampling. The term 'sulfide' (also symbolized in the text as $\mathrm{HS}^{-}$) refers to all species of sulfide $\left(\mathrm{H}_{2} \mathrm{~S}, \mathrm{HS}^{-}\right.$and $\left.\mathrm{S}^{2-}\right)$. Pore water was obtained from a $1 \mathrm{~cm}$ thick core segment, taken $8 \mathrm{~cm}$ below the sedimentwater interface. This depth was chosen in order to ensure a measurement from each core within the burrowing depth of nereids, but below the wave resuspension zone. Pore water from sandy sediments was obtained by centrifuging at $3000 \mathrm{rpm}$ for $4 \mathrm{~min}$. In order to increase speed of sampling no attempts were made to prevent loss of pore water sulfides (evaporation, oxidation) during core sectioning and centrifuging. However, no significant difference was observed between samples from Stns 1, 2 and 3 when compared with results from parallel subsamples taken in a glove bag under $\mathrm{N}_{2}$. Pore water from muddy sediments (fraction of silt and clay $>20 \%$ ) was obtained by squeezing them through a Whatman GF/C glass-fiber filter under $\mathrm{N}_{2}$ (Reeburgh 1967). In all cases, pore water samples were fixed immediately with $5 \% \mathrm{ZnAc}$ to precipitate the sulfide as ZnS (Jørgensen et al. 1990). Samples were subsequently analysed photometrically by the methylene blue technique of Cline (1969). A 1-way analysis of variance (ANOVA) was used to compare the density (no. of individuals $\mathrm{m}^{-2}$ ) at different $\mathrm{HS}^{-}$concentrations.

Subsamples of surface sediment from each core were collected and deep-frozen to insure preservation of organic matter. Sedimentary analysis for all samples was performed following a protocol based on the granulometric methods of Rivière (1977). Organic matter was measured as loss-on-ignition (LOI) at $520^{\circ} \mathrm{C}$ for $6 \mathrm{~h}$ (Kristensen \& Andersen 1987).

Tank experiments. The tank experiments (November 1991 to April 1992) were designed to determine the impact of sulfidic sediment and short-term competitive interactions on the distribution of the 3 nereid species in the Kerteminde Fjord/Kertinge Nor system.

Two different sediments were used: (1) pure sand (from Stn 9); (2) a mixture of 10 parts sand (Stn 9) to 1 part highly sulfidic sediment (Stn 27). The mixture was placed in a closed bucket and stored for 1 wk. Each type of sediment was defaunated by sieving through a $1 \mathrm{~mm}$ mesh sieve. Experimental tanks $\left(0.07 \mathrm{~m}^{2}\right)$ were divided into 2 equal-sized compartments by a removable PVC partition. One compartment was filled with sandy sediment to a depth of $15 \mathrm{~cm}$ and the other with HS $^{-}$sediment to a similar depth. The experimental tanks were left for one week before the introduction of worms in order to allow the sediment to stabilize. Tanks were supplied with running seawater (20\% S) 
under permanent immersion. Water temperature decreased from $11^{\circ} \mathrm{C}$ (November) to $6^{\circ} \mathrm{C}$ (February) and again increased to $8^{\circ} \mathrm{C}$ (April) during the 6 mo experimental period. The partitions were removed $2 \mathrm{~d}$ before the introduction of worms. Nereids were introduced randomly in predetermined numbers. No complementary food was provided. After a $30 \mathrm{~d}$ period the partitions were reinserted and each compartment was examined for the number and species of nereids. Three cores (per compartment) were also collected for pore water $\mathrm{HS}^{-}$concentration, mean particle size and organic matter determination. (See Table 1 for sediment characteristics of each compartment.)

A total of 7 tanks were established: 3 with each of the 3 nereid species alone (allopatry); 3 with 2 species (sympatry); and 1 with all 3 species. The initial density for allopatry was 30 ind. $\operatorname{tank}^{-1}$ (426 ind. $\mathrm{m}^{-2}$ ), and for sympatry $2 \times 15$ and $3 \times 10$ ind. $\tan k^{-1}$. Individuals from all 3 species had a mean fresh towel-dried weight of $0.64 \pm 0.14 \mathrm{~g}$. The experiment was repeated 3 times. Comparisons between means in allopatry and sympatry experiments (\% of worms present in sand compartment, and mortality) were done with a $t$-test. This test was chosen for its robustness with regard to sample sizes and unequal variances (Zar 1984). Probability intervals are symbolized, throughout the text, by $1(0.01<p \leq 0.05), 2(0.001<p \leq 0.01)$ or 3 asterisks $(\mathrm{p} \leq 0.001)$.

A complementary tank experiment was done from 18 April to 28 May 1992 and was designed to observe the preference of Nereis succinea for the presence of mussels (Mytilus edulis) in different types of sediment. A total of 3 tanks were used: one filled with sandy sediment, one filled with HS sediment (same mixture as described above), and one divided as in the preceding experiment, with mussels in the $\mathrm{HS}^{-}$compartment. This experiment was not repeated.

\section{RESULTS}

\section{Nereid distribution in Kerteminde Fjord/Kertinge Nor}

The distribution of nereids in the studied area is shown in Fig. 2. Nereis virens was found throughout the Kerteminde Fjord/Kertinge Nor system except at Stns 19, 21 and 24, which were characterized by large amounts of wood and shell debris. Highest densities (> $500 \mathrm{~m}^{-2}$ ) occurred in the western part of the nor, and lowest densities $\left(<250 \mathrm{~m}^{-2}\right)$ in the eastern part of the fjord (with a small enclave in the eastern part of the nor). Intermediate densities (250 to $500 \mathrm{~m}^{-2}$ ) were found in the western and middle parts of the fjord. In general, densities decreased in the direction of the entrance of the fjord. $N$. succinea was mainly observed
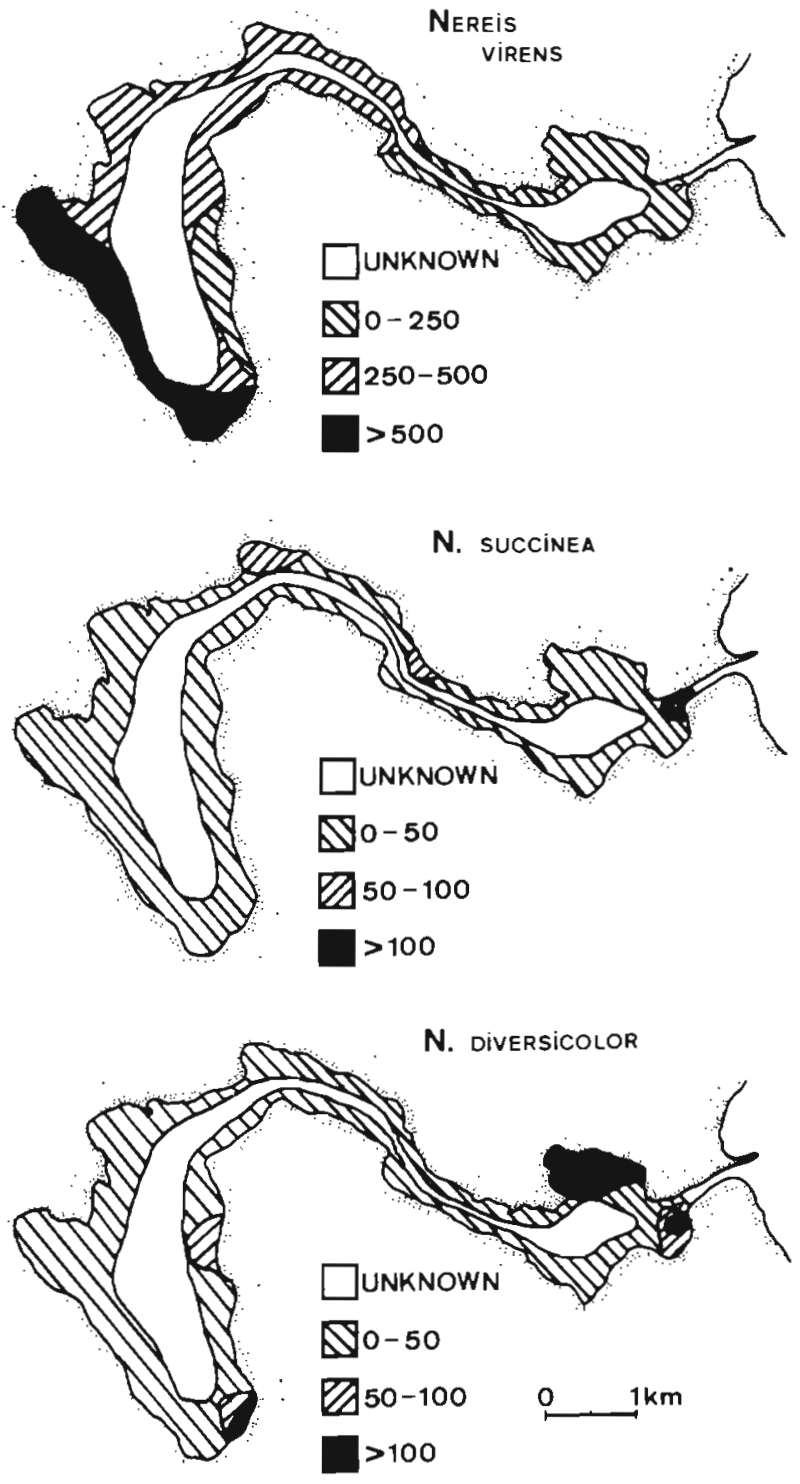

Fig. 2. Nereis spp. Distribution of individuals in study area (values are no. of ind $\mathrm{m}^{-2}$ )

near the mouth of the fjord in a mussel bed $\left(>100 \mathrm{~m}^{-2}\right)$. Two small enclaves (50 to $100 \mathrm{~m}^{-2}$ ) were also found in the middle part of the fjord. $N$. succinea was absent from all other areas. $N$. diversicolor was observed in the eastern part of the fjord and in small areas on the eastern side of the nor. No individuals were found within stations in the middle and western parts of the fjord and on the western side of the nor.

\section{Sediments}

The sedimentary parameters are shown in Table 1. In general, the mean particle diameters (Md) indicate that 
Table 1. Mean particle diameter (Md), silt + clay $(\mathrm{Md}<63 \mu \mathrm{m})$ content, organic carbon (POC) content and sulfide (HS) concentration of sediment from Kerteminde Fjord/Kertinge Nor, and of sediment used in the tank experiment. Values from the field stations are given as means \pm SD of 3 measurements

\begin{tabular}{|c|c|c|c|c|}
\hline Stn & $\begin{array}{c}\mathrm{Md} \\
(\mathrm{mm})\end{array}$ & $\begin{array}{c}\text { Silt + clay } \\
(\%)\end{array}$ & $\begin{array}{r}\text { POC } \\
(\%)\end{array}$ & $\begin{array}{l}\mathrm{HS}^{-} \\
(\mu \mathrm{M})\end{array}$ \\
\hline 1 & $0.96 \pm 0.91$ & $0.87 \pm 1.04$ & $1.25 \pm 0.53$ & $42.17 \pm 34.02$ \\
\hline 2 & $0.32 \pm 0.02$ & $2.16 \pm 2.64$ & $0.50 \pm 0.03$ & $6.54 \pm 5.29$ \\
\hline 3 & $0.19 \pm 0.00$ & $2.45 \pm 0.40$ & $0.90 \pm 0.14$ & $21.09 \pm 8.27$ \\
\hline 4 & $0.19 \pm 0.01$ & $1.60 \pm 1.83$ & $0.87 \pm 0.05$ & $10.67 \pm 7.36$ \\
\hline 5 & $0.36 \pm 0.01$ & $1.50 \pm 0.86$ & $1.32 \pm 0.10$ & $13.60 \pm 4.60$ \\
\hline 6 & $0.29 \pm 0.01$ & $1.52 \pm 1.89$ & $1.14 \pm 0.11$ & $29.79 \pm 10.79$ \\
\hline $7^{a}$ & $0.70 \pm 0.09$ & $0.90 \pm 0.28$ & $1.03 \pm 0.05$ & $7.71 \pm 5.52$ \\
\hline 8 & $0.27 \pm 0.03$ & $1.28 \pm 0.38$ & $0.89 \pm 0.08$ & $13.08 \pm 5.28$ \\
\hline 9 & $0.23 \pm 0.02$ & $3.08 \pm 2.57$ & $0.75 \pm 0.09$ & $12.02 \pm 8.59$ \\
\hline 10 & $0.45 \pm 0.05$ & $4.80 \pm 3.30$ & $0.91 \pm 0.17$ & $1.66 \pm 0.87$ \\
\hline 11 & $0.45 \pm 0.10$ & $1.73 \pm 0.70$ & $1.05 \pm 0.05$ & $4.12 \pm 1.76$ \\
\hline 12 & $0.73 \pm 0.07$ & $3.19 \pm 2.26$ & $1.06 \pm 0.04$ & $2.64 \pm 0.98$ \\
\hline 13 & $0.96 \pm 0.14$ & $2.41 \pm 2.18$ & $0.65 \pm 0.05$ & $8.89 \pm 1.82$ \\
\hline 14 & $1.22 \pm 1.01$ & $12.06 \pm 19.30$ & $0.81 \pm 0.04$ & $0.38 \pm 0.06$ \\
\hline 15 & $0.33 \pm 0.01$ & $1.41 \pm 0.78$ & $0.83 \pm 0.01$ & $6.44 \pm 3.47$ \\
\hline 16 & $0.27 \pm 0.03$ & $1.68 \pm 1.20$ & $0.82 \pm 0.06$ & $6.77 \pm 2.76$ \\
\hline 17 & $0.23 \pm 0.05$ & $3.36 \pm 0.53$ & $1.11 \pm 0.05$ & $25.82 \pm 19.07$ \\
\hline 18 & $0.20 \pm 0.02$ & $6.70 \pm 1.05$ & $1.32 \pm 0.14$ & $42.28 \pm 18.21$ \\
\hline 19 & $0.19 \pm 0.01$ & $4.58 \pm 0.53$ & $0.90 \pm 0.16$ & $21.00 \pm 8.45$ \\
\hline 20 & $0.17 \pm 0.01$ & $2.58 \pm 2.03$ & $1.32 \pm 0.18$ & $30.14 \pm 13.15$ \\
\hline 21 & $0.19 \pm 0.01$ & $6.74 \pm 8.46$ & $0.62 \pm 0.12$ & $32.56 \pm 18.33$ \\
\hline 22 & $0.49 \pm 0.14$ & $4.73 \pm 2.52$ & $0.76 \pm 0.11$ & $4.49 \pm 0.71$ \\
\hline 23 & $0.74 \pm 0.23$ & $1.38 \pm 1.51$ & $0.60 \pm 0.09$ & $1.69 \pm 1.22$ \\
\hline $24^{\mathrm{d}}$ & $0.34 \pm 0.03$ & $2.39 \pm 0.02$ & $0.62 \pm 0.04$ & $7.78 \pm 3.71$ \\
\hline 25 & $0.09 \pm 0.04$ & $55.97 \pm 12.60$ & $11.00 \pm 3.86$ & $90.00 \pm 103.68$ \\
\hline 26 & $0.18 \pm 0.07$ & $36.12 \pm 9.31$ & $15.49 \pm 3.47$ & $550.53 \pm 18.71$ \\
\hline 27 & $0.05 \pm 0.02$ & $67.20 \pm 12.45$ & $15.83 \pm 4.01$ & $1715.30 \pm 1215.11$ \\
\hline $28^{\circ}$ & $0.48 \pm 0.49$ & $21.92 \pm 24.81$ & $4.53 \pm 2.39$ & $587.98 \pm 37.16$ \\
\hline \multicolumn{5}{|c|}{ Tank experiment ( $\mathrm{n}=21$ ): } \\
\hline Sand & $0.50 \pm 0.04$ & $0.00 \pm 0.00$ & $0.66 \pm 0.14$ & $0.85 \pm 0.44$ \\
\hline $\mathrm{HS}^{-}$side & $0.41 \pm 0.01$ & $0.00 \pm 0.00$ & $1.17 \pm 0.05$ & $208.87 \pm 58.09$ \\
\hline
\end{tabular}

between each of the studied sedimentary parameters reflected 3 zones. Differences between the sedimentary parameters from the 2 higher density classes (250-500 and > 500) are, however, small and bidirectionally these 2 sedimentary zones could be merged into one main sedimentary area west of $\operatorname{Stn} 12$, with organic-poor sandy sediment. The low-density area $\left(<250 \mathrm{~m}^{-2}\right)$, east of Stn 12, was characterized by sediments with high silt and clay content and pore water $\mathrm{HS}^{-}$concentrations.

Density of Nereis virens decreased with increasing pore water HS concentration $\left(F_{2,25}=\right.$ $6.49^{\circ}$ ) (Fig. 3). Conversely, the density of $N$. succinea was higher in sediment with $>50 \mu \mathrm{M}$ $\left(F_{2,25}=23.59 \cdots\right)$. This species was, however, almost absent from stations in the 2 other concentration classes $(0-25$ and $25-50 \mu \mathrm{M}$ ). Density of $N$. diversicolor was about the same for the first $2 \mathrm{HS}^{-}$concentration classes $\left(F_{2.25}=0.84\right)$. No individuals were found in stations with sediments having $>50 \mu \mathrm{M} \mathrm{HS}^{-}$.

Results also indicated that the size of individuals (partial weight) varied in relation to the pore water sulfide concentration (Table 3). In spite of a high variablity and a low number of individuals weighed, this trend can be observed particularly for Nereis succinea $(t=-4.08 \cdots)$, where weight (mean) increased by a factor of 6 between the $0-25 \mu \mathrm{M}$ and the $>50 \mu \mathrm{M}$ HS $^{-}$classes. $N$. virens also showed increasing body size between $0-25 \mu \mathrm{M}$ and 25-50 $\mu \mathrm{M}^{-}$- classes $(t=-3.58 \cdots)$. Results did not indicate any significant changes for $N$. diversicolor in regard to weight distribution $(t=-1.93)$. $N$. diversicolor was, however, absent from stations with $\mathrm{HS}^{-}$concentration $>50 \mu \mathrm{M}$.

\section{Transects and coexistence}

The distribution and density of the nereids along the transect in Kerteminde Fjord are shown in Fig. 4A. The distribution of Nereis succinea was related to an area of highly organic and sulfidic sediments within a mussel 
Table 2. Mean particle diameter (Md), silt + clay ( $\mathrm{Md}<63 \mu \mathrm{m})$ content, organic carbon ( $\mathrm{POC}$ ) content and sulfide $\left(\mathrm{HS}^{-}\right)$concentration of sediment from Kerteminde Fjord/Kertinge Nor. Data are pooled according to density classes of Nereis virens. Values are given as means $\pm \mathrm{SE}$. A: $t$-test between classes $0-250$ and $250-500 ; \mathrm{B}: t$-test between classes $0-250$ and $>500 ; \mathrm{C}: t$-test between classes $250-500$ and $>500$

\begin{tabular}{|c|c|c|c|c|}
\hline $\begin{array}{c}\text { Density } \\
\left(\mathrm{m}^{-2}\right)\end{array}$ & $\begin{array}{c}\mathrm{Md} \\
(\mathrm{mm})\end{array}$ & $\begin{array}{c}\text { Silt + clay } \\
(\%)\end{array}$ & $\begin{array}{c}\mathrm{POC} \\
(\%)\end{array}$ & $\begin{array}{l}\mathrm{HS}^{-} \\
(\mu \mathrm{M})\end{array}$ \\
\hline $0-250$ & $\begin{array}{c}0.42 \pm 0.07 \\
\text { A: } t=-3.88 \cdots \\
\text { B: } t=4.24 \cdots \\
\text { (Stns } 1,2,13,14,15\end{array}$ & $\begin{array}{l}10.61 \pm 2.59 \\
t=21.18 \cdots \\
t=21.52 \cdots \\
6,17,18,19,2\end{array}$ & $\begin{array}{l}2.13 \pm 0.51 \\
t=16.12 \cdots \\
t=14.82 \cdots \\
22,23,24,2\end{array}$ & $\begin{array}{c}85.11 \pm 41.05 \\
t=13.00 \cdots \\
t=12.17 \cdots \\
6,27,28 ; \mathrm{n}=49)\end{array}$ \\
\hline $250-500$ & $\begin{array}{c}0.48 \pm 0.05 \\
C: t=6.55 \cdots \\
\text { (Stns } 4,6,10,11\end{array}$ & $\begin{array}{c}2.37 \pm 0.51 \\
t=2.07 \\
n=18)\end{array}$ & $\begin{array}{c}0.94 \pm 0.05 \\
t=-1.37\end{array}$ & $\begin{array}{l}8.43 \pm 2.66 \\
t=-6.36 \cdots\end{array}$ \\
\hline $\begin{array}{l}>500 \\
\cdot p<0.05\end{array}$ & $\begin{array}{c}0.32 \pm 0.08 \\
\text { (Stns } 3,5,7,8,9 i \\
\cdots p>0.01, \cdots p<0\end{array}$ & $\begin{array}{l}1.91 \pm 0.61 \\
=14) \\
01\end{array}$ & $0.98 \pm 0.10$ & $13.50 \pm 1.84$ \\
\hline
\end{tabular}

bed. The other 2 species had higher density outside this area. The same trend was found in Norsminde Fjord (Fig. 4B). N. succinea was found in an area characterized by the presence of Mytilus edulis (from Stn 1 to 6). Sulfide concentrations and organic matter were, however, lower than in the Kerteminde transect. In both transects, $N$. diversicolor was absent from stations where $N$. succinea was found. In this respect, coefficients of coexistence are given in Table 4 . In both study areas, no or only a weak overlap was observed between populations of $N$. succinea and $N$. diversicolor, whereas populations of $N$. succinea and $N$. virens exhibited a high overlap. Populations of $N$. virens and $N$. diversi-

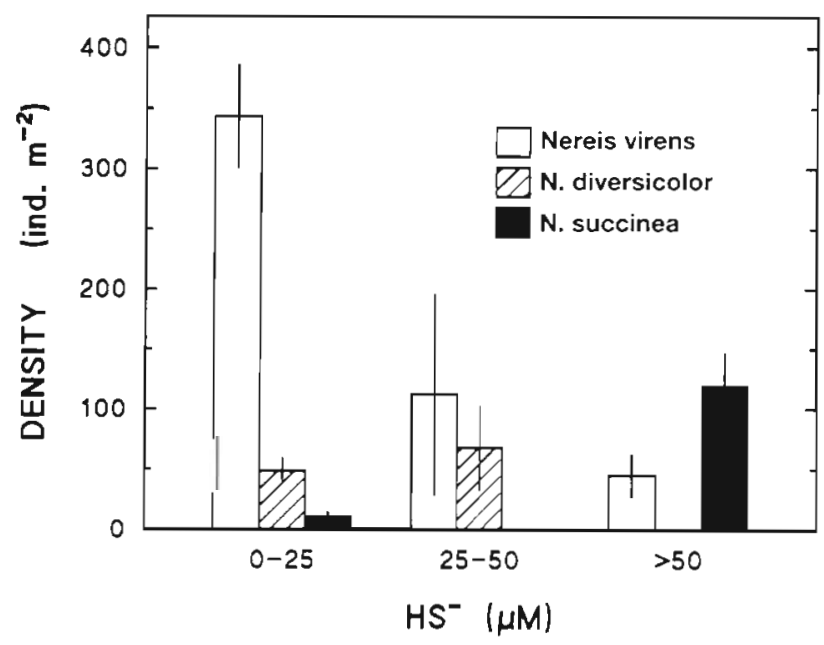

Fig. 3. Nereis spp. Distribution of density in relation to pore water sulfide concentrations (error bars: \pm SE) color showed a partial overlap, which was intermediate between the other 2 population pairs.

\section{Tank experiments}

The tank experiments showed that all 3 species preferred non-sulfidic sediments (Fig. 5). Nereis succinea did, however, show the lowest preference. Results from both allopatry and sympatry experiments indicated that $N$. virens preferred non-sulfidic sediments in all situations, with no significant change between allopatry and sympatry $(t=-0.77$ with $N$. succinea; $t=-0.71$ with $N$. diversicolor). In sympatry with $N$. virens, both $N$. diversicolor $\left(t=3.63^{\circ}\right)$ and $N$. succinea $(t=$ $\left.2.93^{\circ}\right)$ were found in greater number in the sulfidic sediments compared to allopatry. In sympatry with $N$. diversicolor, $N$. succinea was found more often in non-sulfidic sediments $\left(t=2.38^{\circ}\right)$. With all 3 species in sympatry, the percentages of individuals present in the sand compartment were about the same for $N$. virens ( $t=$ -1.53 ) and $N$. diversicolor $(t=0.42)$ compared to results in the paired sympatry experiments. Results for $N$. succinea were intermediate between those of the other 2 sympatry experiments (pairs), and were comparable to those observed in the allopatry situation $(t=0.85)$.

The mortality of all 3 species was usually lower in allopatry than in sympatry. For Nereis virens, mortality increased dramatically from $20 \%$ in allopatry to 40 and $60 \%$ in situations where $N$. succinea was present $(t=$ $-5.80{ }^{\cdots}{ }_{i} t=-5.24 \cdots$ with all 3 species together). $N$. virens was not affected $(t=0.36)$ by the presence of $N$. diversicolor. Mortality of $N$. diversicolor was affected by the presence of other species, although not significantly compared to the allopatry situation $(t=-0.93,-0.36$ and -1.63$) . N$. succinea was not affected significantiy by the presence of $N$. diversicolor $(t=-0.56$ and -0.21$)$. Mortality of $N$. succinea was

Table 3. Nereis spp. Weight (partial weight) distribution in relation to sulfide concentration in Kerteminde Fjord. Values are given as means $\pm \mathrm{SD}$

\begin{tabular}{|lccc|}
\hline Species & \multicolumn{3}{c|}{ Sulfide concentration $(\mu \mathrm{M})$} \\
& $0-25$ & $25-50$ & $>50$ \\
\hline N. virens & $0.08 \pm 0.13$ & $0.20 \pm 0.35$ & $0.10 \pm 0.07$ \\
N. diversicolor & $0.06 \pm 0.06$ & $0.10 \pm 0.08$ & - \\
N. succinea & $0.03 \pm 0.03$ & - & $0.16 \pm 0.14$ \\
\hline
\end{tabular}



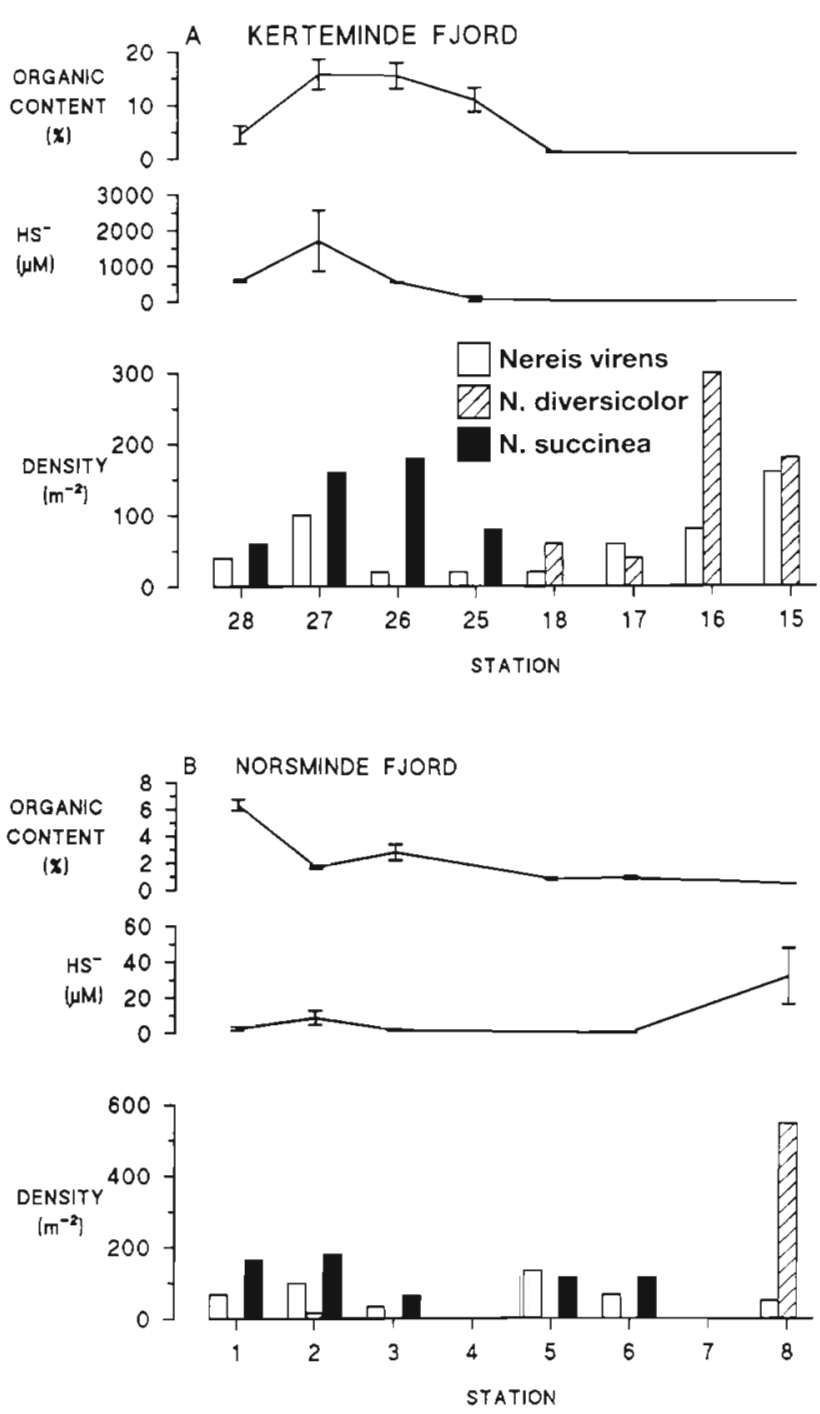

Fig 4. Nereis spp. (A) Distribution of individuals along the Kerteminde transect. (B) Distribution of individuals along the Norsminde transect (see Fig. 1 for location of fjord). Organic content of sediments and pore water sulfide concentrations at the sampling stations are shown (error bars: \pm SE of triplicate cores)

actually lower in sympatry with $N$. virens $\left(t=2.40^{\circ}\right)$ than in allopatry. The slightly elevated mortality rate for $N$. succinea when in sympatry with $N$. diversicolor, compared to values in the case of the 3 species in sympatry, might have been caused by an interruption of the water circulation which occurred in one of the tanks during the third set of replicates.

The tank experiment with mussels present showed that Nereis succinea preferred an association with mussels, whatever the type of sediment used (Fig. 6). The higher preference observed in the sand-mud case, where mussels were positioned on the sulfidic sediment, substantiates this association, since the opposite result was obtained without mussels.
Table 4. Nereis spp. Coefficients of coexistence $\left(C_{i j}\right)$ in Kerteminde Fjord and Norsminde Fjord

\begin{tabular}{|lcc|}
\hline Species combination & $\begin{array}{c}\text { Kerteminde } \\
\text { Fjord }\end{array}$ & $\begin{array}{c}\text { Norsminde } \\
\text { Fjord }\end{array}$ \\
\hline N. succinea $+N$. diversicolor & 0.000 & 0.034 \\
N. virens $+N$. diversicolor & 0.130 & 0.098 \\
N. virens $+N$. succinea & 0.524 & 0.614 \\
\hline
\end{tabular}
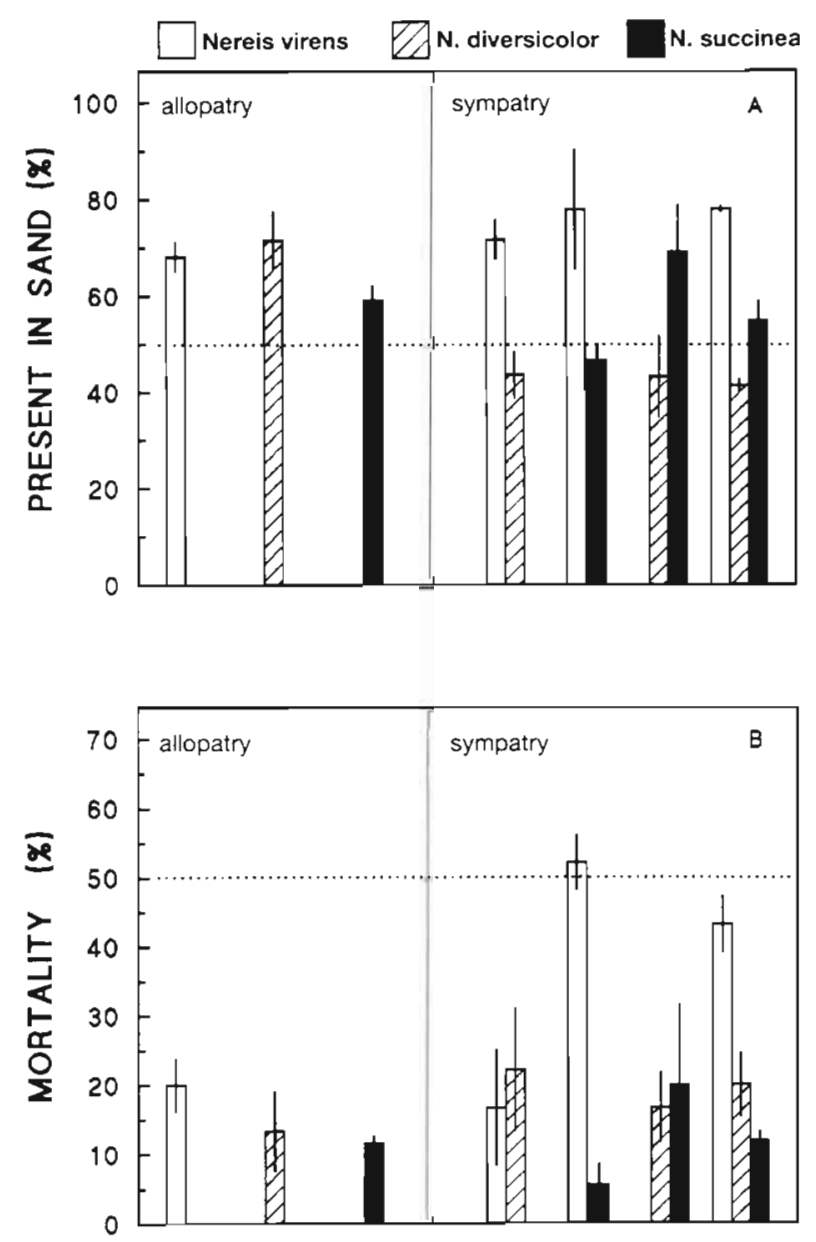

Fig. 5. Nereis spp. (A) Final distribution of individuals in the sand (non-sulfide) compartment after $30 \mathrm{~d}$ incubation in tank experiments. Values are given as \% of the worms present at the end of the experiment. (B) Mortality of individuals after $30 \mathrm{~d}$. Values are given as $\%$ of the initial number of worms added (error bars: \pm SE of triplicate experiments)

\section{DISCUSSION}

Data obtained in this study indicate that Nereis virens is the most common nereid species in the Kerteminde Fjord/Kertinge Nor system. $N$. virens is mainly found in sandy, organic-poor sediments with low levels of pore water sulfides $(<50 \mu \mathrm{M})$. This is in 


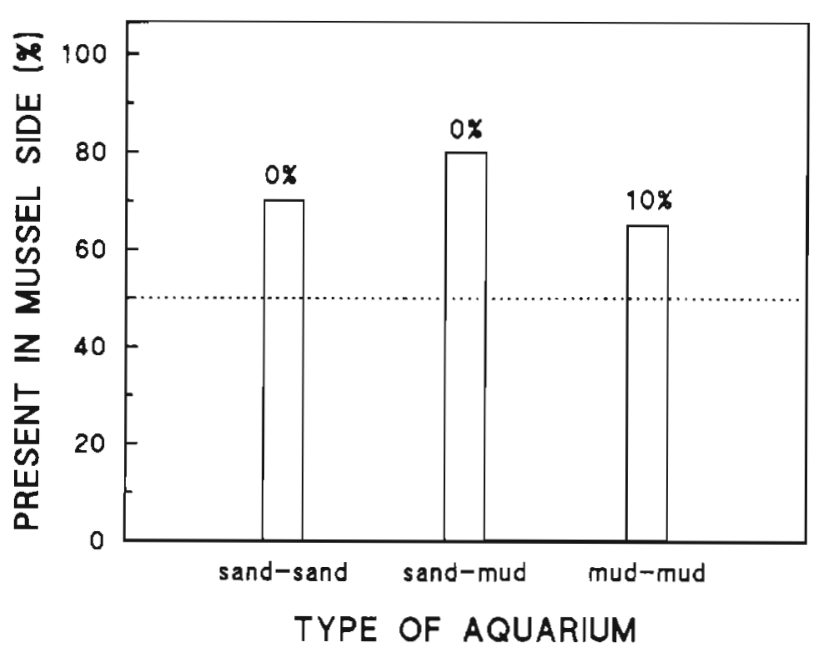

Fig. 6. Nereis succinea. Final distribution of individuals in the mussel side of tanks for different types of sediment. Mussels were positioned on the sulfidic mud side in the sand-mud case. Data are given as \% of the worms present at the end of the experiment. Values above bars are mortality $\{\%\}$

accordance with the distribution of $N$. virens found in a similar estuary in Norsminde Fjord (Kristensen 1988), and in mudflats on the northeast coast of North America (Ambrose 1986, Miron \& Desrosiers 1990). The in situ preference of this species for sandy sediments is in close agreement with results from the tank experiments. The decreasing density toward the more marine habitat (entrance of the fjord) confirms the distribution strategy adopted by $N$. virens in the St. Lawrence estuary (Canada) (Miron \& Desrosiers 1990). Our data, however, failed to reveal any clear weightrelated segregation although larger individuals were found in highly sulfidic sediments near the mouth of the fjord. The high mortality rates observed in the tank experiments, particularly in sympatry conditions (from 20 to $60 \%$ ), illustrate that $N$. virens has a low tolerance to sulfide.

As illustrated in many Danish studies (Muus 1967, Rasmussen 1973, Kristensen 1988), Nereis succinea seems to be limited to mussel beds areas, usually characterized by sulfidic muddy sediments (Theede et al. 1969). This is, however, in contrast with the tank experiments, where this species showed a preference for non-sulfidic sediments. In this respect, the mussel tank experiment illustrated that a mussel-related factor may drive this species toward sulfidic sediments in the natural habitat. Faeces from mussels could attract the detritivore N. succinea (Goerke 1971 . Fauchald \& Jumars 1979). In consequence, this species exhibits a high tolerance for $\mathrm{HS}^{-}$(more than $2000 \mu \mathrm{M}$ sulfide in pore water) in contrast to the omnivorous $N$. virens. In comparison, results from other studies
(Theede et al. 1969, Maughan 1986, Sampou \& Oviatt 1991) indicate that macrofauna is generally excluded from sediments with pore water sulfide concentrations around $1000 \mu \mathrm{M}$. The factors that are responsible for the attraction of $N$. succinea toward mussel beds should be explored in future studies.

In the field study, Nereis diversicolor did not show any specific sediment preference. This is in accordance with Kristensen's (1988) results in Norsminde Fjord. The tank experiment illustrates, as for $N$. succinea, a preference for sandy sediment. The sympatry experiments also show that $N$. diversicolor is highly tolerant to $\mathrm{HS}^{-}$. Our data thus confirm the results of Vismann (1990) which indicated that $N$. diversicolor is more tolerant to $\mathrm{HS}^{-}$than $N$. virens.

Physiological and biochemical adaptations may largely account for the observed differences in the survival ability of polychaetes under hypoxia and anoxia (Warren 1984). The variation in the tolerance of polychaetes to severe hypoxia or anoxia is sometimes reflected in the ecological differences between their habitats (Theede et al. 1973). According to the present results, we must expect a similar or higher rate of $\mathrm{HS}^{-}$ detoxification for Nereis succinea relative to $N$. diversicolor. Tolerance to sulfide can thus extend the animal's ecological niche since $N$. succinea seems attracted by mussels rather than $\mathrm{HS}^{-}$sediments. The fact that $N$. virens and $N$. diversicolor have different rates of $\mathrm{HS}^{-}$ detoxification (sulfide oxidation) illustrates that sulfide is an important factor in determining their distribution. Ventilation rates, which have been well studied in nereids (Kristensen 1981, 1983a, b, c, 1989), may reflect some behavioural or size-specific responses since respiration can be impaired by $\mathrm{HS}^{-}$exposure (Theede et al. 1969). Since ventilation is directly proportional to body weight $(\mathrm{M})$ and burrow wall area increases according to the surface power law ( $\mathrm{M}^{0.7}$ ) (Kristensen 1984), larger worms may be most efficient at removing $\mathrm{HS}^{-}$from burrow water in sulfidic areas. This is confirmed by the fact that larger $N$. virens individuals were found in the sulfidic mussel bed sediment. Further work is needed in order to determine the precise effect of body size on tolerance to sulfide. Jensen (1986), however, found that nematode species had a higher length/body radius ratio in sulfidic (thiobiotic) habitats.

The field data indicate that competitive interactions are an important determinant for the distribution of nereid species. This is particularly true for populations of Nereis diversicolor which do not, or only to a small extent, overlap with populations of $N$. virens and $N$. succinea $\left(C_{1, j}=0.13\right.$ and 0.0 respectively $)$. The sympatry tank experiments substantiate this trend, since $N$. diversicolor was forced into the sulfidic sediment. The mortality rates, which were surprisingly low for this species, show that it actually is highly tolerant to 
$\mathrm{HS}^{-}$. As discussed by Kristensen (1988), the general high tolerance of $N$. diversicolor with respect to many environmental factors has evolved at the expense of competitive ability. In the Kerteminde Fjord/Kertinge Nor system, $N$. diversicolor occupy marginal habitats which, in fact, are refuges from the other 2 species. Aggressive behaviour (territoriality) is important in space-sharing modalities for both $N$. virens (Miron et al. 1991a, b, 1992a, b, c) and $N$. diversicolor (Lambert 1986, Lambert \& Retière 1987, Lambert et al. 1992). Work by Reish \& Alosi (1968) and Evans (1973) also showed that interspecific aggressive behaviour is frequent and must be considered as a factor determining the distribution of nereid polychaetes. The relatively weak interaction between populations of $N$. virens and $N$. succinea observed in the field $\left(C_{i, 1}=0.5\right.$ to 0.6$)$ could be related to the high spatial variability of sulfur biogeochemistry (Luther et al. 1991) rather than low aggressive interactions. Patches of low-sulfidic sediments inside the mussel bed could explain the presence of $N$. virens in the habitat of $N$. succinea. Muus's (1967) views on competitive interactions between $N$. virens and $N$. diversicolor are thus confirmed. Differences in interspecific encounters, with respect to aggressiveness and/or territoriality, among all pairs of the studied species should be described in future studies.

Differences of data for 2-species sympatry combinations compared to those for 3-species combinations suggest that there are complex interactions among the 3 species. Results (\% present in sand) showed that Nereis virens and $N$. diversicolor are unaffected by the addition of $N$. succinea. An intermediate situation is observed for $N$. succinea when present with both $N$. virens and $N$. diversicolor, in contrast to results from the other 2 sympatry situations. These findings suggest that $N$. succinea spatially benefits from the addition of $N$. diversicolor, since more individuals were found in the sand compartment of the tank in comparison to what was observed when $N$. virens was present. In the latter case, $N$. succinea was more evenly distributed throughout the entire tank. Mortality results, however, suggest that $N$. succinea benefits from the addition of N. virens.

The idea of tolerance to abiotic factors as a major part of the niche, and the importance of such factors in determining condition-specific competitive abilities, is an old concept (Grinnell 1917, Allee et al. 1949, Odum 1953, Andrewartha \& Birch 1954, Hutchinson 1958). When species compete, the outcome will be determined primarily, as discussed by Dunson \& Travis (1991), by biotic interactions and the species-specific responses to abiotic factors. According to these authors, physiological responses to abiotic factors could determine the overall conditions of dominance. In the extreme case, condition-specific intensities of competition can cause a reversal of the competitive dominance such that one species is superior under one subset of abiotic conditions, and another species is superior under another subset (Hutchinson 1961).

This study showed that sulfide concentration in sediments may constitute, as do grain size (Wieser 1959, Gray 1974, Rhoads 1974, Miron \& Desrosiers 1990) and salinity (Theede et al. 1973, Kristensen 1988), an important factor in the distribution of softbottom communities. Nereis virens decreased dramatically in density with increasing pore water $\mathrm{HS}^{-}$ concentration. The high mortality rates in the tank experiments corroborated this pattern. A high sulfide tolerance in $N$. succinea (field study) and $N$. diversicolor (tank experiments) allows both of these species to colonize sulfidic sediments. However, low competitiveness forces $N$. diversicolor to inhabit marginal habitats, avoiding interactions with $N$. virens and particularly $N$. succinea. Results from the tank experiments also suggest that a mussel-related factor may be more important than $\mathrm{HS}^{-}$in explaining the distribution of $N$. succinea. We are aware that sulfide is probably correlated with other environmental factors and that these factors play a role in determining the distribution of nereids. Nevertheless, this study should provide interesting field and experimental data for investigating the physiological effect of sulfide exposure, particularly on ventilation behaviour, in nereid individuals (Miron \& Kristensen unpubl.). According to Kristensen $(1981,1983 a, b, c)$, ventilation activity, which is related to $\mathrm{O}_{2}$ regulatory ability, is correlated with preferred sediment type.

Acknowledgements. We are grateful to $\mathrm{H}$. Brandt, S. Andreasen and particularly M. Holmer for much-needed 'laboratory geography' and assistance which made this work much easier. G. Miron was supported by a post-doctoral fellowship grant from the Natural Sciences and Engineering Research Council of Canada and from the Danish Ministry of Education, with the help of the International Council for Canadian Studies (Foreign Government Awards Program).

\section{LITERATURE CITED}

Allee, W. C., Park, O., Emerson, A., Park, T., Schmidt, K. (1949). Principles of animal ecology. Saunders, Philadelphia

Ambrose, W. G. Jr (1986). Estimate of removal rate of Nereis virens (Polychaete: Nereidae) from an intertidal mudflat by gulls (Larus spp.). Mar. Biol. 90: 243-247

Andrewartha, H. G., Birch, L. C. (1954). The distribution and abundance of animals. Univ. of Chicago Press, Chicago

Cline, J. D. (1969). Spectrophotometric determination of hydrogen sulfide in natural waters. Limnol. Oceanogr. 14: $454-458$

Davey, J. T., George, C. L. (1986). Factors in the distribution of intertidal estuarine polychaetes, a field experiment 
with Nereis (Hedistes) diversicolor and Nephtys caeca in the Tamar at Plymouth. Estuar coast. Shelf Sci. 22 $603-618$

Degn, H., Kristensen, B. (1981). Low sensitivity of Tubifex sp. respiration to hydrogen sulfide and other inhibitors Comp. Biochem. Physiol. 69: 809-817

Desrosiers, G. Vincent, B., Retière, C., Boucher, L. (1988) Comparaisons de deux méthodes utilisées comme critère biométrique pour le polychète Nereis virens. Can. J. Zool 66: $1454-1459$

Dunson, W. A., Travis, J. (1991). The role of abiotic factors in community organization. Am. Nat. 138: 1067-1091

Evans, S. M. (1973). A study of fighting reactions in some nereid polychaetes. Anim. Behav. 21: 138-146

Fauchald, K., Jumars, P. A. (1979). The diet of worms: a study of polychaete feeding guilds. Oceanogr. mar. Biol. A. Rev. 17: $193-284$

Fenchel, T (1969). The ecology of marine microbenthos. 4 Structure and function of the benthic ecosystem, its chemical and physical factors and the microfauna communities with special reference to the ciliated protozoa. Ophelia 6: 1-182

Fitzhugh, K. (1984). Temporal and spatial patterns of the polychaete fauna on the central northern Gulf of Mexico continental shelf. In: Hutchings, P. A. (ed.) Proc. 1st Int Polychaete Conf. Sydney, Australia. Linnean Society of New South Wales, Sydney, p. 211-225

Fjordbiologisk Laboratorium (1992). Effekter af reduceret næeringastofbelastning på den biologiske struktur, stofomsætning og stoftransport i fjord. Statusrapport. Fjordbiologisk Laboratorium, Kerteminde, Denmark

Funen County Council (1991). Eutrophication of coastal waters. Coastal water management in the county of Funen, Denmark, 1976-1990. Legislation - Nutrient loads and eutrophisation effects - Causes and trends. Funen County Council, Department of Technology and Environment, Odense $S \varnothing$

Fyns Amt (1992). Vandmiljoovevågning-Kystvande 1991 Teknik og miljoforvaltningen Vand/miljoafdelingen. Fyns Amt, Odense $S \varnothing$

Goerke, H. (1971). Die Ernährungsweise der Nereis-Arten (Polychaeta: Nereidae) der deutschen Küsten. Veröff. Inst. Meeresforsch. Bremerh. 13: 1-50

Gray, J. S. (1974). Animal-sediment relationships. Oceanogr mar. Biol. sm. Rev. 12: 223-261

Grinnell, J. (1917). The niche-relationship of the California thrasher. Auk 34: 427-433

Hutchinson, G. E. (1958). Concluding remarks. Cold Spring Harbor Symp. quant. Biol. 22: 415-427

Hutchinson, G. E. (1961). The paradox of the plankton. Am Nat. 95: $137-145$

Hylleberg, J., Nateewathana, A. (1984). Temporal and spatial distribution of nephtyid polychaetes at Phuket Island, Andaman Sea. In: Hutchings, P. A. (ed.) Proc. 1st Int. Polychaete Conf. Sydney, Australia. Linnean Society of New South Wales, Sydney, p. 292-302

Jensen, P. (1986). Nematode fauna in the sulphide-rich brine seep and adjacent bottoms of the East Flower Garden, NW Gulf of Mexico. Mar. Biol. 92: 489-503

Jørgensen, B. B. (1977). The sulfur cycle of a coastal marine sediment (Limfjorden, Denmark). Limnol. Oceanogr. 22: $814-832$

Jørgensen, B. B. (1980). Seasonal oxygen depletion in the bottom waters of a Danish fjord and its effect on the benthic community. Olkos 34:68-76

Jørgensen, B. B., Bang, M., Blackburn, T. H. (1990). Anaerobic mineralization in marine sediments from the Baltic
Sea-North Sea transition. Mar. Ecol. Prog. Ser. 59: 39-54

Kristensen, E. (1981). Direct measurements of ventilation and oxygen uptake in three species of tubicolous polychaete (Nereis spp.). J. comp. Physiol. 145: 45-50

Kristensen, E. (1983a). Ventilation and oxygen uptake by three species of Nereis (Annelida: Polychaeta). I. Effects of hypoxia. Mar. Ecol. Prog. Ser. 12: 289-297

Kristensen, E. (1983b). Ventilation and oxygen uptake by three species of Nereis (Annelida: Polychaeta). II. Effects of temperature and salinity changes. Mar. Ecol. Prog. Ser. 12: $299-306$

Kristensen, E. (1983c). Comparison of polychaete (Nereis spp.) ventilation in plastic tubes and natural sediments. Mar. Ecol. Prog. Ser. 12: 307-309

Kristensen, E. (1984). Life cycle, growth and production in estuarine populations of the polychaetes Nereis virens and N. diversicolor. Holarct. Ecol., Copenhagen 7: 249-256

Kristensen, E. (1988). Factors influencing the distribution of nereid polychaetes in Danish coastal waters. Ophelia 29: $127-140$

Kristensen, E. (1989). Oxygen and carbon dioxide exchange in the polychaete Nereis virens: influence of ventilation activity and starvation. Mar. Biol. 101.381-389

Kristensen, E., Andersen, F. Ø. (1987). Determination of organic carbon in marine sediments: a comparison of two CHN-analyzer methods. J. exp. mar. Biol. Ecol. 109: $15-23$

Lambert, R. (1986). Etude de la territorialité chez Nereis diversicolor; approche méthodologique. Diplôme d'Etudes Avancées, Univ. de Rennes I, Rennes

Lambert, R., Desrosiers, G., Retière, C., Miron, G. (1992). Activité de prospection de son aire d'alimentation par la polychète Nereis diversicolor $(\mathrm{O}$. F. Müller): données préliminaires. Cah. Biol. mar. 33: 43-54

Lambert, R., Retière, C. (1987). Etude de la territorialité chez les adultes de Nereis diversicolor (Annélide Polychète). C. r. Acad. Sci. Paris III 305: 643-647

Llanso, R. J. (1991). Tolerance of low dissolved oxygen and hydrogen sulfide by the polychaete Streblospio benedicti (Webster). J. exp. mar. Biol. Ecol. 153: 165-178

Luther, G. W. III, Ferdelman, T. G., Kotstka, J. E., Tsamakis, E. J, Church, T. M. (1991). Temporal and spatial variability of reduced sulfur species $\left(\mathrm{FeS}_{2}, \mathrm{~S}_{2} \mathrm{O}_{3}{ }^{2-}\right.$ ) and porewater parameters in salt marsh sediments. Biogeochemistry 14 : $57-88$

Maughan, J. T (1986). Relationship between macrobenthic fauna and organic carbon. Dissertation. Univ. of Rhode Island, Kingston

Miron, G. Y., Desrosiers, G. L. (1990). Distributions and population structures of two intertidal estuarine polychaetes in the lower St. Lawrence estuary, with special reference to environmental factors. Mar. Biol. 105: 297-306

Miron, G., Desrosiers, G., Retière, C. (1992a). Activité de prospection de son aire d'alimentation par le polychète Nereis virens (Sars) en conditions constantes d'éclairement et d'obscurité C. R. Acad. Sci. Paris III 314: 455-460

Miron, G., Desrosiers, G., Retiere, C. (1992b). Organization of fighting in the polychaete Nereis virens (Sars) and the effects of residency and orientation. Behaviour 121. 20-34

Miron, G., Desrosiers, G., Retière, C., Lambert, R. (1991a). Dispersion and prospecting behaviour of the polychaete Nereis virens (Sars) as a function of density. J exp. mar. Biol. Ecol. 145: 65-77

Miron, G., Desrosiers, G., Retière, C., Masson, S. (1992c). Variations in time budget of the polychaete Nereis virens in relation to density and acclimation after introduction to a new burrow. Mar. Biol. 114:41-48 
Miron, G., Desrosiers, G., Retière, C., Lambert, R. (1991b). Evolution spatio-temporelle du réseau de galeries chez le polychète Nereis virens (Sars) en relation avec la densité. Can. J. Zool. 69: 39-42

Muus, B. J. (1967). The fauna of Danish estuaries and lagoons Distribution and ecology of dominating species in the shallow reaches of the mesohaline zone. Meddr Danm. Fisk. og Havunders. 5: 1-316

Odum, E. P. (1953). Fundamentals of ecology. Saunders, Philadelphia

Powell, E. N., Bright, T. J., Woods, A., Gitting, S. (1983). Meiofauna and the thiobios in the East Flower Garden brine seep. Mar. Biol. 83: 269-283

Rasmussen, E. (1973). Systematics end ecology of the Isefjord marine fauna (Denmark). Ophelia 11: 1-507

Reeburgh, W. S. (1967). An improved interstitial water sampler. Limnol. Oceanogr. 12: 163-165

Reish, D. J., Alosi, M. C. (1968). Aggressive behavior in the polychaetous annelid family nereidae. Bull. South Calif. Acad. Sci. 67: 21-28

Revsbech, N. P., Jorgensen, B. B. (1986). Microelectrods: their use in microbial ecology. Adv. microb. Ecol. 9: 293-352

Rhoads, D. C. (1974). Organism-sediment relations on the muddy sea-floor. Oceanogr. mar. biol. A. Rev. 12: 260-300

Rivière, A. (1977). Méthodes granulométriques: techniques et interprétation. Masson, Paris

Sampou, P., Oviatt, C. A. (1991). A carbon budget for a eutrophic marine ecosystem and the role of sulfur metabolism in sedimentary carbon, oxygen and energy dynamics. J. mar. Res. 49: 825-844

Schoener, S. H. (1974). Some methods for calculating competition coefficients from resource-utilization spectra. Am. Nat. 108: $332-340$

Spotila, J. R., Standora, E. A., Easton, D. P., Rutledge, P. S. (1989). Bioenergetics, behavior and resource partitioning

This article was submitted to the editor in stressed habitats: biophysical and molecular approaches. Physiol. Zool. 62: 253-285

Stachowitsch, M. (1984). Mass mortality in the Gulf of Trieste the course of community destruction. P.S.Z.N. I: Mar. Ecol. 5: $243-264$

Swanson, R. L., Sinderman, C. J. (1979). Oxygen depletion and associated benthic mortalities in New York Bight, 1976. National Oceanic and Atmospheric Administration Prof. Pap. 11, Rockville, MD

Theede, H., Ponat, A., Hiroki, K., Schlieper, C. (1969). Studies on the resistance of marine bottom invertebrates to oxygen-deficiency and hydrogen sulfide. Mar Biol. 2: 325-337

Theede, H., Schaudinn, J., Saffe, F. (1973). Ecophysiological studies on four Nereis species of the Kiel Bay. Oikos 15: $246-256$

Torrans, E. L., Clemens, H. P. (1982). Physiological and biochemicals effects of acute exposure of fish to hydrogen sulfide. Comp. Biochem. Physiol. 71: 183-190

Vismann, B. (1990). Sulfide detoxification and tolerance in Nereis (Hedistes) diversicolor and Nereis (Neanthes) virens (Annelida: Polychaeta). Mar. Ecol. Prog. Ser. 59: $229-238$

Warren, L. M. (1984). How intertidal polychaetes survive at low tide. In: Hutchings, P. A. (ed.) Proc. 1st Int. Polychaete Conf. Sydney, Australia. Linnean Society of New South Wales, Sydney, p. 238-253

Wieser, W. (1959). The effect of grain size on the distribution of small invertebrates inhabiting beaches of Puget Sound. Limnol. Oceanogr. 4: 181-194

Woodin, S. A. (1974). Polychaete abundance pattern in a Maine soft sediment environment: the importance of biological interaction. Ecol. Monogr, 44: 171-187

Zar, J. H. (1984). Biostatistical analysis, 2nd edn. PrenticeHall, Englewood Cliffs

Manuscript first received: August 11, 1992

Revised version accepted: December 14, 1992 